\title{
Empowering Female Farmers Against Mining Capitalism
}

\author{
Miftahul Huda, ${ }^{1}$ Alfa Chusna ${ }^{2}$ \\ ${ }^{1}$ Universitas Islam Negeri Sunan Kalijaga, \\ Yogyakarta-Indonesia, ${ }^{2}$ Sekolah Tinggi \\ Ilmu Farmasi (STIFAR) Semarang - \\ Indonesia
}

Corresponding Author: Miftahul Huda, email: miftahhuda1932@gmail.com, J. Laksda Adisucipto. Depok, Sleman, Daerah Istimewa Yogyakarta 55281

\begin{abstract}
Women mostly depend on agriculture, which indicates that women have their economic resources to help the family economy. The presence of the Kulon Progo Coastal Farmers Association of Farmers is the beginning of a bright future for farmers, women. This article discusses the empowerment of women in the Kulon Progo Coast Farmers Association. The purpose of this study is to find out how far women can be empowered with the organization of the Kulon Progo Coastal Farmers Association. This research is a qualitative study with data collection techniques using a purposive sample. The data collection process is done by indepth interviews and snowball after the key informant is found. The data obtained were analyzed using the Longwe analysis framework. The results of this study indicate that female farmers are equal in agricultural areas, but in the political domain (organization) female farmers are still below male farmers.
\end{abstract}

Keywords: empowerment; female farmer; mine

Abstrak: Perempuan sebagian besar menggantungkan dirinya pada pertanian yang menandakan perempuan memiliki sumber ekonomi sendiri untuk membantu perekonomian keluarga.Kehadiran organisasi Paguyuban Petani Lahan Pantai Kulon Progo (PPLP-KP) merupakan awal masa depan yang cerah bagi petani, perempuan. Artikel ini membahas pemberdayaan perempuan dalam organisasi Paguyuban Petani Lahan Pantai Kulon Progo. Tujuan studi ini adalah untuk mengetahui seberapa jauh perempuan bisa berdaya dengan adanya organisasi Paguyuban Petani Lahan Pantai Kulon Progo. Penelitian ini merupakan penelitian kualitatif dengan teknik pengumpulan data menggunakan purposive sample. Proses pengumpulan data dilakukan dengan cara wawancara mendalam dan snow ball setelah informan kunci ditemukan. Data yang diperoleh dianalisis menggunakan kerangka analisis Longwe. Hasil penelitian ini menunjukkan bahwa petani perempuan telah setara di wilayah pertanian, namun di dalam wilayah politik (organisasi) petani perempuan masih berada di bawah petani laki-laki.

Kata Kunci: pemberdayaan; petani perempuan; tambang 


\section{A. Introduction}

The iron sand mine in Kulon Progo, Yogyakarta, is planned to be operationalized in 2012 by PT Jogja Magasa Iron (JMI). Its operational value reaches Rp. 16,83 trillion. According to JMI director, Satya Graha, the mine is expected to produce iron ore, reaching 1 million tonnes per year. While JMI is the Work of Contract for 30 years between PT Jogya Magasa Mining (JMM) and Indo Mines Ltd Australia, which form a joint venture. The shares are $70 \%$ controlled by Indo Mines and 30\% by JMM. While the area of mining concessions reach 2.987 hectares that will make it as the first Work of Contract in Java Island. After the mining operation reaches 5 years, the production capacity of PT JMI will be estimated to reach 5 million tonnes per year. The project will also potentially make the first iron sand mine in Indonesia and make the second in the world after New Zeland. ${ }^{1}$

The operation of the iron sand mine has the potential to contribute a royalty of Rp. 49 billion per year for local governments. The revenue share system is based on Government Regulation Number 45 of 2003 regarded the Upper Rates Type of the Non-Tax Country Admission, taking into consideration the financial center and region. ${ }^{2}$ Indeed, the area would benefit from the activity of mines, at least in the economy. But it should also be seen from another more substantial perspective. For example, ecological issues that become a source of community income around mines. It means that the mining activities should not disturb even kills economic activity of the community and environment.

Judging from the viewpoint of ecofeminism, utilization, or rather the exploitation of nature for the profit sector is a life-reducing attitude. Capitalism categorizes "the value" of which can generate profits in the commercial industry, while those that unvalued will be considered useless. Nature, as an ecosystem for the life of living beings, is seen as unvalued during its utilization is not found. To realize the value of benefits in the economic sector, road

1Sutami Sutami, Kulon Progo Tak Biarkan Alih Fungsi Tambang, ed. Agus Priyanto, Antara Yogya (Yogyakarta, 2018), https://jogja.antaranews.com/berita/353507/kulon-progo-tak-biarkanalih-fungsi-tambang; Yahya Yahya, "Tambang Pasir Besi Yogya Beroperasi," Tender-Indonesia, 2012, https://indonesia-tender.blogspot.com/2012/01/tambang-pasir-besi-yogya-beroperasi.html.

2Pamuji Tri Nastiti, “Tambang Pasir Besi: Pemkab Kulon Progo Incar Royalti Rp. 49,16 Miliar per Tahun," Ekonomi Bisnis.Com, June 30, 2013, https://ekonomi.bisnis.com/read/20130630/ 44/147886/tambang-pasir-besi-pemkab-kulon-progo-incar-royalti. 
exploitation, and extractions that prove nature can be utilized. Of course, this reductionism view does not see the effect of the extraction and exploitation activity of human life. ${ }^{3}$

Human beings as a living entity directly in contact with nature and are members of the environment, can certainly feel the impact of the iron sand mining activities. For women, mining activity is a disaster. With the scientific revolution that was merely looking at women and nature as a source of benefit for anthropocentric life, the law of nature is regarded as an incompatibility that must be eliminated as the legitimacy of natural exploitation while women become the most harmed entity. 4

Research on Argoposo C. showed women in four villages affected by iron sand mine activity to give resistance. The resistance arose from the consciousness of women who felt their farmland was threatened. Besides, it was also demonstrated that women could access the public area. Based on conflicts between communities facing the mining corporation, Argoposo used ecofeminism as an approach, but could not yet see the empowerment of women in the agriculture and organizational sector. So, it was necessary to analyze the level of empowerment of women in the organization and agriculture area. ${ }^{5}$ While in research Dina Novia showed that women perform multiple roles in her life as well as the level of female empowerment was still relatively low. The result aims to promote increased female empowerment from various sectors. ${ }^{6}$ It differs from this research that identifies conflicts between corporations and farmer organizations that also seek to empower women farmers.

In March 2019 became the 13th anniversary of the establishment of the Association Farmers Coastal Land of Kulon Progo (PPLP-KP) 7 to defend the

3Vandana Shiva and Maria Mies, Ecofeminism: PerspektifGerakan Perempuan dan Lingkungan, trans. Kelik Ismunanto Lilik (Yogyakarta: IRE Press, 2005), 29.

${ }^{4}$ Shiva and Mies, 34.

${ }^{5}$ Argoposo C. Nugroho, "Bertani di Atas Pasir Pesisir Pantai Selatan Yogyakarta: Studi Kasus Perempuan Melawan Tambang Pasir Besi," in Ekofeminisme III: Tambang, Perubahan Iklim, dan Memori Rahim, ed. Dewi Candraningrum and Arianti Ina Restiani Hunga (Yogyakarta: Jalasutra, 2015), 104-17.

${ }^{6}$ Dina Nova Priminingtyas, "Akses Dan Kontrol Perempuan Kepanjen Malang terhadap Tanah, Uang dan Harta Kekayaan," in Ekofeminisme II: Narasi Iman, Mitos, Air dan Tanah, ed. Dewi Candraningrum (Yogyakarta: Jalasutra, 2014), 159.

7Paguyuban Petani Lahan Pantai Kulon Progo. 
coastal land in four villages. The solidarity and consistency of this organization in the fight has been fruitful; that is no operation of iron mines until now, although its Work of Contract still leaves 17 years. With the success of farmers retains their land, then planting as the main livelihood can be resumed.

This study examines the organization of PPLP-KP, which emerged as a rejection of the establishment of iron sand mine PT JMI. ${ }^{8}$ PPLP-KP accommodates not only male farmers but also female farmers. Work as a farmer is always done together between husband and wife by sharing assignments. Women are usually taking care of the land, and men care parts that rely on physically. However, some women also work on the part that is commonly done by men. The division of work on the land is always carried out every day. At the same time, the wife must finish the domestic work before leaving for the area.

The community incorporated in the organization of PPLP-KP is categorized in moderate gender, ${ }^{9}$ namely women serve in the domestic areas and men work in the public areas. Sometimes women also work to get income, but it will be regarded as an additional income for the family. Gender relations will differ in the PPLP-KP, where men and women have the same rights in accessing natural resources, even winning them together. Although there are still some roles that gender bias is still. The gender is a legacy of the Suharto government that imposed the ideology of "state ibuism" as the best choice of a woman in carrying out the role. 10

This article is a result of qualitative research in following the activity of PPLP-KP farmers. The technique of collecting data on this research using purposive sampling, ${ }^{11}$ while it processed by way in-depth interviews. In the process of collecting data, the researcher determined the key informant that is concerned with the social conditions that will be researched as primary data. The researcher also used secondary data: documentation and addition of

\footnotetext{
${ }^{8}$ Nugroho, "Bertani di Atas Pasir Pesisir Pantai Selatan Yogyakarta: Studi Kasus Perempuan Melawan Tambang Pasir Besi," 104. 102.

${ }^{9}$ Alimatul Qibtiyah, Feminisme Muslim di Indonesia (Yogyakarta: Suara Muhammadiyah, 2019),

${ }^{10}$ Qibtiyah, 103.

11Suyitno, Metode Penelitian Kualitatif: Konsep, Prinsip dan Operasionalnya, ed. H. Ahmad Tanzeh (Tulungagung: Akademia Pustaka, 2018), 95.
} 
informant with snowball technique ${ }^{12}$ to obtain the widest information about the research object. Further analysis of data was done with the data reduction technique,13 this article will further discuss the empowerment of female farmers in the PPLP-KP organization and analyzed using the Longwe analysis framework.

The result of this research showed that PPLP-KP was very influential in women farmers ' empowerment. Farmer access to the land can be resumed after they succeeded in subverting mine capitalism. Although female farmers got the highest level of empowerment in agriculture, the political area was still low compared to male farmers.

\section{B. Women Empowerment Longwe Perspective}

Women and men farmers, do have different experiences in carrying out the role of gender. But both have the same capacity to solve the problems that arise in public areas. Simultaneously, women farmers in taking their roles tend to be adaptive, adjusting what is men's decisions. Ivan Illich refers to it as a domestic gender (vernacular) that bases on all acts of men and women in complementary properties. ${ }^{14}$

In line with the "state ibuism" ideology emphasized in the Suharto era, domestic gender was born as a configuration of the state ibuism. As much as anything, female activity will be deemed useless if the primary role of educating the child as a primary responsibility is not exercised. Such sexual construction certainly raises gender injustices and triggers the marginalization of women. The impoverishment of women, subordination in political affairs, the formation of stereotype, violence, the number of workloads (burden) of women ${ }^{15}$ is a representation of the marginalization of women.

Since the New Order era (President Soeharto, Orba), women's strategic and practical needs have been discussed and offered. But in fact, the

12Suyitno, 96.

${ }^{13}$ Sandu Siyoto and M. Ali Sodik, Dasar Metodologi Penelitian, ed. Ayup (Yogyakarta: Literasi Media Publishing, 2015), 122-23. 47-48.

${ }^{14}$ Ivan Illich, Matinya Gender, trans. Amin Mukti, 6th ed. (Yogyakarta: Pustaka Pelajar, 2007),

15Fakih Mansour, Analisis Gender dan Transformasi Sosial, 10th ed. (Yogyakarta: Pustaka Pelajar, 2013), 12. 
development offered since Orba is difficult to answer the strategic needs of women--to not say the needs of practical and strategic of women are also less fulfilled or even not. According to Mansour Fakih, development depends heavily on the context of who is using it and for what interests. ${ }^{16}$ In this context, Longwe argues that women need to achieve equality in participation and control of the development process, such as access to education, economic equality, and control over production tools. If equality is achieved, women can escape the structural poverty caused by the oppression and exploitation of. ${ }^{17}$

To find out if women have been empowered, it is necessary to include a framework of analysis from Longwe. Empowerment here is interpreted as women's equality in accessing and controlling economics, education, employment, and so on. Longwe has five levels of equality that shows up to where women empowerment has been achieved, as shown in Figure 1.18

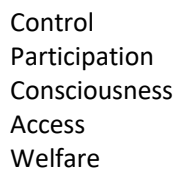

Control

Consciousness

Welfare

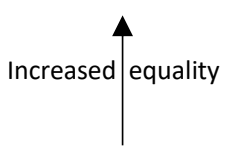

Figure 1.

Longwe's five levels of equality

The chart above explains that equality is hierarchical, the higher the development focus the higher the level of women's empowerment. Hierarchically, welfare is the lowest level of equality gained by women. In the first level, women are only passive entities and receive only the benefits of development. The question is whether women can access resources, such as receiving food supplies, medical care, and so forth. Suppose women receive equal wages with men as a farmer.

On the second level namely access, where female empowerment is called increased if women have access to land, resources, a credit equal to men. Access

16Mansour, 27-28.

${ }^{17}$ Smyth March and M. Mukhopadhyay, A Guide to Gender Analysis Frameworks, 3rd ed. (British: Oxfam GB, 2005), 92-93.

${ }^{18}$ March and Mukhopadhyay, 93-94. 
here intends to show the opportunity between men and women. At this level, women begin to access sources of oppressor and exploitation.

The third level is consciousness, at this level gives the understanding that gender is a social construction that can be changed which certainly has the potential to change the role of women in the working area. Recognition of equality in the division of work and no political domination of one of any gender must be fulfilled. The most fundamental is the awareness of sexual equality is the basis of gender equality. The fourth level is participation, to achieve at this level of development should involve women in decision making, assessment, and evaluation of a program. This level of equality requires the participation of women to achieve proportional development.

Control is the fourth level, this is the highest level in women's equality. Achievement at this level required women who control the co-development of men to supervise utilization, distribution, and production. With the presence of control women with men aim to eliminate or at least reduce the dominative possibility of one gender. And the top levels of equality is called as a tool to analyze the extent of development supporting equality and empowering women. The basis of the empowerment is the equality of rights and the place that women have acquired with men in the development process to achieve the benefits of production. These equality hierarchies do not close the possibilities when higher levels are achieved while the levels below are not reached. It is heavily influenced by male and female relationships in culture and political decisions.

The existence of an analysis framework from Longwe is to measure up to where practical and strategic needs women are met. The understanding of practical needs is what women should get today and also when they need, such as freshwater, food availability, bathroom, reproductive health services, access to capital, and credit. While women's strategic needs are what women need to obtain for the long term and potentially eliminate the imbalance between men and women. Examples of such strategic needs, women's access to land, laws governing the inclusion of women in the government bureaucracy, the similarity of rights in the opinion. That's the goal of women's empowerment according to Longwe, not only touching things that are practical but also political. 


\section{Farmer Vs. Iron Sand Mine Conflict: PPLP-KP's Effort to Empower Female Farmers}

The land is not merely a possession in the form of a licensed certificate, nor merely possession in physical form. For farmers, the land is a space where culture, social relations, and economic turnover take place. Even the land is a space of spirituality, there is an intimate relationship between farmers to land, with nature that has given it a source of livelihood. ${ }^{19}$ On the land, farmers found their relationship with God, so rejection until the fight against the environment destroyer is very reasonable.

The people of Kulon Progo, especially the villages of Galuran, Bugel, Karangsewu, Pleret, who depend themselves on the sand of the south coast hasa threat from the iron sand mine. Not only agriculture land, but also the resident's settlements are also threatened to be affected by the establishment of the iron sand mine. $22 \mathrm{~km} \times 1.8 \mathrm{~km}$ is the area of mining in the Work of Contract and the workforce required as many as 8,000 people. While 30,000 people affected by establishing iron sand mines are threatened to lose agriculture land and settlements. ${ }^{20}$ That means the company will produce a lot of unemployment because the work in the mines is more accessible to men and it also competes with the newcomers.

In addition to unemployment and competing with migrant workers, the emergence of mine capitalism also has the potential to impoverish female farmers and change their established gender relationships. According to the principle of Bacon using the term "vexation" by making nature as an object of experimentation, because it is considered to contain something that can be utilized by humans. Creating technology is a solution to be able to know the natural content. ${ }^{21}$ So that happens is the extraction and exploitation of the potentially damaging life on it, namely plants, animals, and humans themselves. Based on research, the impact of coastal sand dredging will damage the ecological balance. The beach she-oak (Casuarina equisetifolia) and natural dune is the most

\footnotetext{
${ }^{19}$ Abdur Rozaki, "Konflik Agraria, Perempuan dan Kemiskinan di Desa," Musãwa: Jurnal Studi Gender dan Islam 15, no. 1 (2016): 46, https://doi.org/10.14421/musawa.2016.151.39-57.

${ }^{20}$ Nugroho, "Bertani di Atas Pasir Pesisir Pantai Selatan Yogyakarta: Studi Kasus Perempuan Melawan Tambang Pasir Besi," 104.

${ }^{21}$ Carolyn Merchant, Autonomous Nature: Problems of Prediction and Control From Ancient Times to the Scientific Revolution (New York: Routledge, 2016), 83-84.
} 
effective tsunami holder. Besides, a layer of sand above the ground is a natural earthquake reducer and will eliminate its function if the sand is dredged up by the mine. $^{22}$

The emergence of mine capitalism has raised conflicts between farmers against institutions that initiated the establishment of mines, including corporations and governments. According to Dahrendorf, the emergence of conflicts caused by the significance of the authority clash with subordinates that want change. ${ }^{23}$ In this case, the Special Region of Yogyakarta has distributed its authority by permitting mining to extract the natural content, namely iron sand. The mining project does not violate RTRW based on Regulation of the Regent of Kulon Progo Number 40 of 2005 regarded Spatial Plan of South Beach Area year 2005-2015. But the community adhered to the letter X/PA/2003 that is provided by KGPAA Paku Alam IX to the head Bapedalda on 7 January $2003^{24}$ which confirms that the land of Paku Alam Ground can be utilized by the surrounding community and should not change physical and biological forms as well as mining. The very political decision issued by the Government certainly poses a conflict for farmers who still want farmland that has been managed for many years. Maintaining land is an absolute choice for farmers.

Stems from the government's decision to permit miners, Kulon Progo community work together to defend the agricultural land. So formed PPLP-KP that has been established for 13 years, since the year 2006 the organization has been fighting against the iron sand mines. There are four villages in the organization of PPLP-KP, such as the villages of Karangsewu, Garongan, Pleret, and Bugel. ${ }^{25}$ The resistance will continue as long as their farmland is in various kinds of threats from corporations. Indeed, the effort of PPLP-KP is to maintain the balance of nature and maintain a living space for the next generation.

${ }^{22}$ Bambang Yunianto, “Kajian Permasalahan Lingkungan dan Sosial Ekonomi Rencana Penambangan dan Pengolahan Pasir Besi di Pantai Selatan Kulon Progo," Jurnal Teknologi Mineral Dan Batubara 5, no. 1 (2009): 10, https://doi.org/10.30556/jtmb.Vol5.No1.2009.911.

${ }^{23}$ George Ritzer and Douglas J Goodman, Teori Sosiologi: Dari Teori Sosiologi Klasik Sampai Perkembangan Mutakhir Teori Sosial Postmodern, trans. Nurhadi, 10th ed. (Yogyakarta: Kreasi Wacana, 2014), 284.

${ }^{24}$ Sri Hartati Samhadi, Ahmad Arif, and Maria Hartiningsih, eds., "Petani Berhadapan dengan Kekuasaan," Kompas.Com, April 11, 2008, https://nasional.kompas.com/read/2008/04/11/ 00432262/petani.berhadapan.dengan.kekuasaan?page=all.

${ }^{25}$ Nugroho, "Bertani di Atas Pasir Pesisir Pantai Selatan Yogyakarta: Studi Kasus Perempuan Melawan Tambang Pasir Besi," 106. 
PPLP-KP has no data on the number of farmers, either division by gender or the total number of farmers who join the organization. However, Eko, one of the officers of PPLP-KP, stated that there were 5,000 more farmers and almost every farmer had their self-directed land. The purpose of this organization itself was to defend the farmland located on the sand of the beach. A wide range of innovations had been created by farmers in managing land. Such as irrigation using the sumur renteng (renteng well) by mix the fertilizer into the well and made the point of waterways every 8 meters. So farmers do not have to carry water with the bucket, enough with the hose that will be connected to the waterways point. The invention makes it easier for farmers, especially female farmers. In addition to facilitating, the invention of technology is also a strategic effort to optimize women's capabilities. ${ }^{26}$

The innovation of PPLP-KP farmers by incorporating technology into the agricultural region is a female-friendly effort. Bringing the memory of the Suharto era about the Green Revolution policy that boils down to the creation of small capitalists and imbalances of land ownership. ${ }^{27}$ Incorporating technology with agriculture also causes women to lose income due to limited ability to operate modern technology in the management of land. Also, the Green Revolution program focuses only on male farmers, as if wanting to say that farmers are men's jobs. ${ }^{28}$ But what happens in the organization PPLP-KP explains the status of women in the fields, they remain farmers. Not only that, the technological support that makes it easy for women to farming is also created.

With this organization, the livelihood of people, especially women can be continued, namely farming. The threat of iron sand mine is an experience for women to continue to reject the establishment of the mine. Waljiati, a female farmer also voiced the threat of the establishment of mine. It argued that if the mine operated, then the loss of agriculture while the establishment of the mine only emphasizes the ruling elite advantage that was later also monopolized by the corporation. ${ }^{29}$

${ }^{26}$ Agus Eko Sujianto, “Kampanye Teknologi yang Ramah Perempuan,” Musãwa: Jurnal Studi Gender dan Islam 5, no. 3 (2007): 365-80, https://doi.org/10.14421/musawa.2007.53.365-380.

${ }^{27}$ Noer Fauzi Rachman, "Petani dan Penguasa: Dinamika Perjalanan Politik Agraria Indonesia” (Yogyakarta: INSIST Press, 2017), 166-67.

28Mansour, Analisis Gender dan Transformasi Sosial, 73.

${ }^{29}$ Waljiati, Interview, May 4, 2019 
As Vandana Shiva said, the feature of development in the modern world is to alienate the resource of those who most need, depriving ecology and eliminating one's control over the source of life, namely nature. ${ }^{30}$ That is why female farmers would rather fight for their land to letting mines operate. By farming, women can produce their economies while helping the family economy. Therefore, women are also conscious, to be an empowered woman, farmed is the best road, on the other hand, also empowers the environment. Through the path of the organization PPLP-KP, women empowerment can be realized, not only practical but also strategic.

PPLP-KP was a response to the major threats that will occur against nature. Implicitly, women become the most threatened organisms. Various efforts were undertaken by the PPLP-KP to maintain agricultural and community settlement, among others, through the law line, negotiations and the coercion to bring about a radical change. One of the most effective forms of resistance for the community is to continue planting. Planting for farmers is a form of resistance to the natural destroyer. In addition to repelling the mines, planting is a productive activity, thus alienating the farmer community from, the so-called Conrad Lodziak, ${ }^{31}$ a consumptive culture. Resistance also requires organized movements, so the PPLP-KP continues to self-fix so that organizational objectives can be realized.

Improvement in the body of the organization and always learn from experience is capital for the organization and everyone who is in the organization. One of the efforts to strengthen the organization is every result of the discussion of farmers, PPLP-KP always provides information to the organizations in the village, either the female organization or RT/RW. So similarity in farming and quality of agricultural produce as much as possible similar. PPLP-KP also provides a place of the harvest auction as a form of accommodation of the organization to the farmers, for now just chili pepper is auctioned off. Then, the result of the chili auction, the farmers are taxed for the organization and later used also by farmers. Its use can be various, such as saving loans for land managing capital, healthcare services, organization events, and others.

\footnotetext{
30Shiva and Mies, Ecofeminism: PerspektifGerakan Perempuan dan Lingkungan, 83.

${ }^{31}$ Conrad Lodziak, The Myth of Consumerism (London: Pluto Press, 2002), 11.
} 
Every farmer in Kulon Progo had their land, but not all landowners become independent farmers. Farmers usually contract their land to other farmers to be hired and landowners can also work as farmworkers in their land. Such phenomena are common in PPLP-KP, the factors are lack of capital. Meanwhile, the minimum wage of farmworkers is Rp. 70,000 once work starts from 8 am to $4 \mathrm{pm}$, the work provider also gives a banquet such as gorengan and lunch for farmworkers.

When there was a farmer's job vacancy, it becomes an opportunity for female farmers. As Ponco said, that the woman (wife) nobody was unemployed. Most of them will be farmworkers if there were neighbors or others who need labor, and loss for women who did not take advantage of those opportunities. ${ }^{32}$ Unlike Robert Alan Sessions' concerns about the dysfunctional system,33 that is men are real workers and are paid, while unpaid ones are referred to as women's jobs (men supporters). The community has realized how to create a functional working system by giving women access to resources. Women are not treated as "back up", but as workers as men acquire equal rights.

The above definition shows that women also have access to public areas to help the family economy. Although women/wives also need to complete the domestic area before leaving for the public areas. Women only worked in the domestic area when they were pregnant, had babies, sick, and something more important than farming. Nur Hidayah also conveyed, in addition to assisting the husband in the field, the wife ordinary to be a farmworker, the wife did not access resources if the domestic area was more in need of women. ${ }^{34}$

PPLP-KP also speaks the role of women in the organization. According to Widodo PPLP-KP was open to anyone, both men or women, to participate in discussions or associations. But the participation of women is lacking because it conflicts with cultures that gave negative stigma to women who were out of the night. So women choose to stay at home and receive any results of the discussion. Widodo also conveyed that men and women relationships such as today were strong and solid, ${ }^{35}$ which is moderate gender relations. But when in

\footnotetext{
32Ponco, Interview, April 30, 2019.

${ }^{33}$ Robert Alan Sessions, "Ecofeminism and Work," in Ecofeminism: Women, Culture, Nature, ed. Karen J Warren (Indiana: Indiana University Press, 1997), 182.

${ }^{34}$ Nur Hidayah, Interview, May 4, 2019.

35Widodo, Interview, May 2, 2019.
} 
PPLP-KP men and women have the same access to resources, the marketing of crops, and of course the role of women in caring for the land is very influential in the sustainability of the planting process until harvesting.

While the role of PPLP-KP in gender awareness is still somewhat lacking. As Widodo said above, that the community is already solid and the struggle against the mines succeeded because of men's and women's relationships based on moderate gender. Concern if there is a raise gender awareness formally - is, the solidity of the community will wobbly and the effort against the mines is changing focus to the issues of gender relations that change not necessarily match the character of the community resistance. PPLP-KP does not want to be busy with such problems, because with their moderate gender relations is strong and solid.

Statement from Widodo in the above-received recognition from Siti Nur Janah stating that men and women already had a common right, that is to access resources with the form of farming and become a farmworker. ${ }^{36}$ It is acknowledged by women as a manifestation of equal rights between men and women. The similarity of the right to plant (farming) signifies men and women together in opposition to the mining corporation.

The struggle to maintain a living environment is not an activity performed by one gender. Women who are often said to be the closest entity and connected to nature are not always true. The aspect of the experience with nature can be possessed by anyone, either men or women. Victoria Davion ${ }^{37}$ has said, not all women feel connected to nature. It is possible for men to feel the connectedness of nature more than women. The phenomenon that occurs in the people of Kulon Progo has clarified what Davion has emphasized about the connectedness of nature with humans that do not perceive gender.

\section{Female Farmer Empowerment Level Analysis}

It can be drawn a line about gender consciousness by the organization of PPLP-KP, which is direct to the technical sphere, not in the realm of theory. They immediately practiced how men and women could be solid and strong in

\footnotetext{
36Siti Nur Janah, Interview, May 4, 2019

${ }^{37}$ Catriona Sandilands, The Good-Natured Femnist: Ecofeminist and the Quest for Democracy (London: University of Minnesota Press, 1999), 75.
} 
defending their land and living space, namely by farming to form shared consciousness. The consciousness that is formed is that the preservation of nature and the living space needs to be guarded for the balance of nature.

As for decision making by women in the organization is very low, because of the lack of participation of women in each discussion. Culture affects women's participation, stereotypical for women who are out of the night. While the schedule of each meeting is always nighttime and not possible to be changed because the family of farmers every morning until the afternoon must be on their land and leaving only the night.

The overview of the women empowerment above will be analyzed using the Longwe Framework tool 1:38

Welfare: In this organization men and women have the same access to health care, get fertilizer subsidies, women farmers can also earn their income from the outcome of being a farm worker with an equivalent salary with men.In terms of welfare, female farmers receive the benefit of policies determined by the organization. If iron sand mines operate, most likely women will lose the job. Besides, domestic needs will be threatened by mines, such as water and land influence in domestic work, where women in society with traditional gender (moderate), borrowed the term Carolyn Merchant about the Conservation Trilogy, fighting for the conservation of true womanhood, the home, and the children. ${ }^{39}$

Access: Female farmers have the same access to manage farmland. Managing the soil tends to alternate between the husband and wife. Such as irrigation that is easily operationalized by women and the knowledge of the type of fertilizer that is easily accessible, so that the management of land can be maximal. Likewise marketing, PPLP-KP provides a marketing office that facilitates male and female farmers in marketing their harvest. Women can also become farmworkers who certainly influence the family economy.Likewise, for business purposes, women can access credit on their behalf. Organizations have intervened to empower female farmers to this level.

\footnotetext{
38March and Mukhopadhyay, A Guide to Gender Analysis Frameworks, 93.

${ }^{39}$ Carolyn Merchant, Earthcare: Women and the Environment (New York: Routledge, 1996), 128.
} 
Consciousness: PPLP-KP does not give gender consciousness to its members because the organization's focus is against the mining corporation.On the other hand, the consciousness that women are an important organism for natural sustainability has been lifted in commemoration of the 13th PPLP-KP anniversary. Likewise, in the commemoration of the Syawalan in 2017, women expressed the attitude that they would continue to struggle to defend the land with men indicating they were present and acquired equal rights. ${ }^{40} \mathrm{But}$ at this level the intervention of organizations in giving gender awareness to its members is still very lacking, according to the data that can be, only once, that is through a ceremonial event. The result of a culture that perpetuated the stigma against women still existed, such as women who were out of the night had a negative view.

Participation: Participation and decision-making by women in PPLP-KP are relatively low, especially in meeting activities. This is because the schedule of meetings and discussions is always carried out at night. A negative view of women who were in the night was still in the village. While to change the schedule of meetings and discussion is hampered by the daily farming schedule lasts from morning to afternoon, although PPLP-KP also does not prohibit women to participate. Women are more often participating in any ceremonial event such as the anniversary celebration of PPLP-KP. Women are tasked with providing banquets and men preparing places and supplies. While women's participation in mining rejection is not negligible, women have made up their struggle.The absence of organizational intervention in gender consciousness levels affects women's participation in the organization. At this level, women only participate in the field of work, while in participating organizations is very low.

Control: Organisational control holders are more dominated by men, the motto "mothers accept whatever the fathers decide" is still a grip by society. While selling harvest, some women can sell it themselves. At this level, women have control over land equal to men, as in traditional gender, husband and wife discuss together on land management. Unlike when in organizations, women do not have control, so they cannot influence culture and political decisions that benefit women.

\footnotetext{
${ }^{40}$ Abdus Somad, "Gaung Perempuan Menolak Sultan Ground (SG) Dan Pakualaman Ground (PAG)," Selamatkan Bumi, July 13, 2017, http://selamatkanbumi.com/id/gaung-perempuanmenolak-sultan-ground-sg-dan-pakualaman-ground-pag/.
} 
Table 1.

The role of men and women based on workspaces and politics

\begin{tabular}{clcccc}
\hline \multirow{2}{*}{ No. } & \multicolumn{2}{c}{ Level } & \multicolumn{2}{c}{ Agriculture } & \multicolumn{2}{c}{$\begin{array}{c}\text { Political } \\
\text { Participation }\end{array}$} \\
\cline { 3 - 6 } & & Men & Women & Men & Women \\
\hline 1 & Welfare & $\mathrm{V}$ & $\mathrm{V}$ & $\mathrm{V}$ & $\mathrm{V}$ \\
2 & Access & $\mathrm{V}$ & $\mathrm{V}$ & $\mathrm{V}$ & $\mathrm{V}$ \\
3 & Consciousness & $\mathrm{V}$ & $\mathrm{V}$ & $\mathrm{V}$ & - \\
4 & Participation & $\mathrm{V}$ & $\mathrm{V}$ & $\mathrm{V}$ & - \\
5 & Control & $\mathrm{V}$ & $\mathrm{V}$ & $\mathrm{V}$ & - \\
\hline
\end{tabular}

The findings above can be represented in a Table 1 by dividing 2 areas, namely production in agricultural land and political participation in the PPLPKP organization.

Based on the table above indicates that the level of female equality in the agricultural sphere has reached the fifth level. This suggests that the practical needs of women have been achieved and are a good condition for the empowerment of women in the agricultural sphere equivalent to men. But within the political area of women empowerment is relatively low, women reach only at the level of welfare and access. While men reach the fifth level in the organization. This is a less good condition for women because to achieve the strategic needs of women and the political balance in organizations need to involve women in the political area.

\section{E. Conclusion}

PPLP-KP was an organization that appears to respond to environmentally damaging corporations along with the institutions that were behind it. Agriculture and the environment are sectors where the organization was moving to save a life. The iron sand mine became an enemy to the organization and the resistance had lasted for 13 years. Neither men nor women have made a fight against the mine. Thanks to PPLP-KP women can access resources that had been threatened by mining that also threaten gender relations and health. As an organization that grew in a rural area, man and women relationships adhere to moderate gender, men as leaders while women play a role in households and this is effective enough for farmer families who are in the conflict area. The need to measure the level of empowerment is to balance the role of men and women in the organization or the work area. In agricultural 
areas, women are at a very good level of empowerment. But within organizations, women are at a low level of empowerment. Of course, this can lead to an imbalance between men and women in the future, so it is necessary to involve women in political space to stabilize the organization in the long term interests.

The PPLP-KP organization needs to involve women in political space within the organization. With the involvement of women in the political space, the long term organizational balance can be realized. Besides, the experience of women needs to be conveyed and taken into consideration, through the political path women can convey the experience and the injustices that he experienced. As for the cultural issues that still adopt the state of the New Order's legacy state ibuism need to be removed slowly. Women, in addition to their disadvantaged also reproduce the stereotype. It is very necessary because the good and bad of men and women based on social construction, not sex. [s]

\section{References}

Illich, Ivan. Matinya Gender. Translated by Amin Mukti. 6th ed. Yogyakarta: Pustaka Pelajar, 2007.

Lodziak, Conrad. The Myth of Consumerism. London: Pluto Press, 2002.

Mansour, Fakih. Analisis Gender dan Transformasi Sosial. 10th ed. Yogyakarta: Pustaka Pelajar, 2013.

March, Smyth, and M. Mukhopadhyay. A Guide to Gender Analysis Frameworks. 3rd ed. British: Oxfam GB, 2005.

Merchant, Carolyn. Autonomous Nature: Problems of Prediction and Control From Ancient Times to the Scientific Revolution. New York: Routledge, 2016.

___ Earthcare: Women and the Environment. New York: Routledge, 1996.

Nastiti, Pamuji Tri. “Tambang Pasir Besi: Pemkab Kulon Progo Incar Royalti Rp. 49,16 Miliar per Tahun." Ekonomi Bisnis.Com, June 30, 2013. https://ekonomi.bisnis. com/read/20130630/44/147886/tambang-pasir-besi-pemkab-kulon-progoincar-royalti.

Nugroho, Argoposo C. "Bertani di Atas Pasir Pesisir Pantai Selatan Yogyakarta: Studi Kasus Perempuan Melawan Tambang Pasir Besi.” In Ekofeminisme III: Tambang, 
Perubahan Iklim, Dan Memori Rahim, edited by Dewi Candraningrum and Arianti Ina Restiani Hunga. Yogyakarta: Jalasutra, 2015.

Priminingtyas, Dina Nova. "Akses dan Kontrol Perempuan Kepanjen Malang terhadap Tanah, Uang dan Harta Kekayaan." In Ekofeminisme II: Narasi Iman, Mitos, Air Dan Tanah, edited by Dewi Candraningrum. Yogyakarta: Jalasutra, 2014.

Qibtiyah, Alimatul. Feminisme Muslim di Indonesia. Yogyakarta: Suara Muhammadiyah, 2019.

Rachman, Noer Fauzi. "Petani dan Penguasa: Dinamika Perjalanan Politik Agraria Indonesia." Yogyakarta: INSIST Press, 2017.

Ritzer, George, and Douglas J Goodman. Teori Sosiologi: Dari Teori Sosiologi Klasik Sampai Perkembangan Mutakhir Teori Sosial Postmodern. Translated by Nurhadi. 10th ed. Yogyakarta: Kreasi Wacana, 2014.

Rozaki, Abdur. "Konflik Agraria, Perempuan dan Kemiskinan di Desa." Musãwa: Jurnal Studi Gender Dan Islam 15, no. 1 (2016): 39-57. https://doi.org/10.14421/ musawa.2016.151.39-57.

Samhadi, Sri Hartati, Ahmad Arif, and Maria Hartiningsih, eds. "Petani Berhadapan dengan Kekuasaan.” Kompas.Com, April 11, 2008. https://nasional.kompas. com/read/2008/04/11/00432262/petani.berhadapan.dengan.kekuasaan?pag $\mathrm{e}=$ all.

Sandilands, Catriona. The Good-Natured Femnist: Ecofeminist and the Quest for Democracy. London: University of Minnesota Press, 1999.

Sessions, Robert Alan. "Ecofeminism and Work." In Ecofeminism: Women, Culture, Nature, edited by Karen J Warren. Indiana: Indiana University Press, 1997.

Shiva, Vandana, and Maria Mies. Ecofeminism: Perspektif Gerakan Perempuan Dan Lingkungan. Translated by Kelik Ismunanto Lilik. Yogyakarta: IRE Press, 2005.

Siyoto, Sandu, and M. Ali Sodik. Dasar Metodologi Penelitian. Edited by Ayup. Yogyakarta: Literasi Media Publishing, 2015.

Somad, Abdus. "Gaung Perempuan Menolak Sultan Ground (SG) dan Pakualaman Ground (PAG)." Selamatkan Bumi, July 13, 2017. http://selamatkanbumi. com/id/gaung-perempuan-menolak-sultan-ground-sg-dan-pakualamanground-pag/.

Sujianto, Agus Eko. "Kampanye Teknologi yang Ramah Perempuan." Musãwa: Jurnal Studi Gender dan Islam 5, no. 3 (2007): 365-80. https://doi.org/10.14421/ musawa.2007.53.365-380. 
Sutami, Sutami. Kulon Progo Tak Biarkan Alih Fungsi Tambang. Edited by Agus Priyanto. Antara Yogya. Yogyakarta, 2018. https://jogja.antaranews.com/ berita/353507/kulon-progo-tak-biarkan-alih-fungsi-tambang.

Suyitno. Metode Penelitian Kualitatif: Konsep, Prinsip dan Operasionalnya. Edited by H. Ahmad Tanzeh. Tulungagung: Akademia Pustaka, 2018.

Yahya, Yahya. "Tambang Pasir Besi Yogya Beroperasi." Tender-Indonesia, 2012. https://indonesia-tender.blogspot.com/2012/01/tambang-pasir-besi-yogyaberoperasi.html.

Yunianto, Bambang. "Kajian Permasalahan Lingkungan dan Sosial Ekonomi Rencana Penambangan dan Pengolahan Pasir Besi Di Pantai Selatan Kulon Progo." Jurnal Teknologi Mineral dan Batubara 5, no. 1 (2009): 1-16. https://doi.org/ 10.30556/jtmb.Vol5.No1.2009.911. 
This page intentionally left blank. 